\title{
PENINGKATAN PENDIDIKAN GIZI (COOKING CLASS) KELOMPOK KADER POSYANDU (MP-ASI)
}

\author{
Amellia Mardhika ${ }^{1,2 *}$, Anestasia Pangestu Mei Tyas ${ }^{1}$, Fanni Okviasanti1,2, Lailatul \\ Fadliyah $^{1,3}$, Arina Qona'ah ${ }^{2}$, Joko Susanto ${ }^{1,2}$, Hafna Ilmi Muhalla ${ }^{1,2}$ \\ ${ }^{1}$ Fakultas Vokasi, Universitas Airlangga, Surabaya, Indonesia \\ Jl. Dharmawangsa Dalam No. 28-30 (Kampus B) Surabaya \\ ${ }^{2}$ Fakultas Keperawatan, Universitas Airlangga, Surabaya, Indonesia \\ Jl. Mulyorejo (Kampus C) Surabaya \\ ${ }^{3}$ Fakultas Kedokteran, Universitas Airlangga, Surabaya, Indonesia \\ Jl. Mayjen Prof. Dr. Moestopo No.47, Surabaya, Indonesia \\ "Email : ameliamardhika@vokasi.unair.ac.id
}

\begin{abstract}
Abstrak
Stunting merupakan kondisi kekurangan gizi kronis yang merupakan akibat dari kurangnya asupan gizi dalam jangka waktu lama, sehingga menyebabkan anak mengalami gangguan pertumbuhan. Salah satu upaya pencegahan stunting dilakukan melalui pemberian Makanan Pendamping ASI (MP-ASI) yang dapat diberikan oleh kader posyandu dengan bahan dasar kelor. Tujuan pengabdian masyarakat ini agar kader dapat memaksimalkan meja ke empat posyandu yaitu memberikan penyuluhan bahkan mengajarkan kepada ibu balita tentang cara membuat MP-ASI. Pelaksanaan pendidikan gizi (cooking class) dilaksanakan pada bulan JuniAgustus 2019 yang diikuti oleh 10 kader dari 2 posyandu. Metode yang dilakukan adalah pelatihan kader, pendampingan dan evaluasi. Hasil dari pendidikan pendidikan gizi ini adalah peningkatan pengetahuan dan keterampilan kader dalam melaksanakan tugas kader pada meja 4 posyandu sehingga ibu balita dapat mempraktikkannya dirumah.
\end{abstract}

Kata kunci : cooking class, kelor, kader, posyandu

\section{PENDAHULUAN}

Kurang gizi kronis atau yang disebut dengan stunting merupakan akibat dari asupan gizi yang kurang pada anak dalam kurun waktu lama, yang mengakibatkan terjadinya gangguan pertumbuhan pada anak. Anak akan mempunyai tinggi badan yang lebih pendek dari standar tinggi badan anak seusianya. Faktor keturunan seringkali dianggap sebagai penyebab stunting, sehingga tidak ada upaya pencegahan yang dilakukan. Padahal telah diketahui bahwa faktor keturunan mempunyai kontribusi paling kecil dalam mempengaruhi kejadian stunting jika dibandingkan dengan faktor lain yaitu pelayanan kesehatan, perilaku dan lingkungan (ekonomi, budaya, sosial, politik) (Depkes RI 2018).

Stunting di Lamongan selama 3 tahun di tahun 2015, 2016 dan 2017 terdapat 28,80\%; $25,20 \%$ dan 23\%. Butuh komitmen dari pemerintah untuk menurunkan stunting sehingga Kementerian Dalam Negeri menerbitkan instruksi terintegrasi tanggal 20 Maret 2018 yakni Nomor 440/1959/SJ bahwa di Kabupaten Lamongan prioritas penurunan stunting terdapat di 10 desa pada Tahun 2018 (Tim Nasional Percepatan Penanggulangan Kemiskinan 2018).

Sustainable Development Goals (SDGs) mempunyai target, salah satunya adalah penurunan stunting dimana pada tujuan yang kedua mempunyai tujuan padat Tahun 2030, menghilangkan kelaparan, memperbaiki malnutrisi, dan mencapai ketahanan pangan. Untuk mewujudkan hal tersebut, saat ini pemerintah berfokus pada pencegahan kondisi anak stunting. Pencegahan stunting bertujuan untuk memaksimalkan dan mengoptimalkan tumbuh kembang anak-anak Indonesia dengan kemampuan fisik, sosial dan emosional, serta dapat berkompetisi dan berinovasi di tingkat global (Depkes RI 2018).

Upaya pencegahan kondisi stunting dilakukan melalui intervensi gizi spesifik dan gizi sensitif. Intervensi gizi spesifik diberikan pada 1.000 Hari Pertama Kehidupan (HPK) anak dan memberikan kontribusi sebanyak 30\% dalam menurunkan kejadian stunting. Intervensi dilakukan fokus pada bidang kesehatan serta berlangsung dalam waktu yang relatif singkat, meliputi intervensi gizi spesifik dengan sasaran pada ibu hamil dan ibu menyusui dengan anak usia 0-6 
bulan dan usia 7-23 bulan. Intervensi kedua yaitu Intervensi Gizi Sensitif yang dilakukan diluar bidang kesehatan melalui berbagai kegiatan pembangunan dan memberikan kontribusi sebanyak $70 \%$ dalam menurunkan kejadian stunting. Masyarakat umum merupakan sasaran dari intervensi gizi spesifik dan tidak hanya khusus pada ibu hamil namun juga mencakup balita di 1.000 HPK.

Kegiatan pada Intervensi Gizi Sensitif ini dapat dilakukan melalui kegiatan-kegiatan yang pada umumnya makro dan dilaksanakan secara lintas Kementerian dan Lembaga dimana akses terhadap air bersih sanitasi tersedia, melaksanakan fortifikasi bahan pangan, akses untuk layanan Keluarga Berencana (KB) dan layanan kesehatan baik, tersedianya Jaminan Persalinan Universal (Jampersal), Jaminan Kesehatan Nasional (JKN), memberikan edukasi kepada orangtua dalam pengasuhan anak, memberi pendidikan pada Anak Usia Dini (PAUD) secara universal, edukasi terhadap gizi masyarakat, gizi pada remaja, serta kesehatan reproduksi dan seksual, memberikan bantuan serta jaminan sosial pada keluarga dengan ekonomi rendah dimana perlu peningkatan ketahanan pangan dan gizi bagi masyarakat (Tim Nasional Percepatan Penanggulangan Kemiskinan, 2018).

Salah satu intervensi gizi spesifik dimana intervensi ini merupakan intervensi dengan target pada anak dengan usia 7-23 bulan yaitu pemberian Makanan Pendamping ASI (MP-ASI). MP-ASI adalah makanan peralihan dari Air Susu Ibu (ASI) ke makanan anggota keluarga. Baik dari segi bentuk ataupun jumlahnya, pemberian dan pengenalan MP-ASI sebaiknya dilakukan dengan cara bertahap. Penyesuaian ini bermanfaat dalam membantu kemampuan penerimaan MP-ASI pada alat pencernaan bayi (Depkes RI 2006). Bahan-bahan makanan diantaranya adalah telur ayam, kacangkacangan, hati ayam, ikan, tempe, sayur mayur dan buah-buahan yang segar, dapat menghasilkan jenis MP-ASI yang baik (Yanti and Oktaviani 2012).

Bayi atau anak memerlukan protein, vitamin, energi, lemak, mineral dan zat tambahan lain sebagai syarat khusus yang harus dipenuhi dalam MP-ASI (Siregar 2014). Pemenuhan mikronutrien seperti zat besi (Fe), zinc (Zn) kurang terpenuhi pada MP-ASI yang disediakan dan dibuat sendiri oleh keluarga atau rumah tangga (MP-ASI tradisional) apalagi jika keluarga tersebut mempunyai tingkat ekonomi rendah (Ibnu, Syafar, and Awaluddin 2018). Pembuatan MP-ASI oleh keluarga akan cukup untuk memenuhi kebutuhan gizi bayi atau anak apabila sumber bahan makanan bergizi yang tersedia dilakukan pengaturan dengan baik dari segi variasi maupun jumlah yang dibutuhkan masing-masing bayi atau anak.

Moringa oleifera atau kelor merupakan spesies yang paling terkenal dari genus Moringacae yang lain. Tanaman kelor dapat tumbuh secara cepat merupakan sebagai salah satu tanaman popular saat ini dan mempunyai banyak sarat gizi. Daun kelor memiliki kandungan yang melebihi wortel pada kandungan betakaroten, kandungan protein yang lebih tinggi dari kacang polong, mengandung vitamin $\mathrm{C}$ yang lebih banyak pada jeruk, kandungan kalsium yang lebih tinggi dari kandungan kalsium pada susu, kandungan zat besi yang juga lebih banyak dari kandungan zat besi pada bayam dan kandungan pada kaliumnya lebih banyak daripada buah pisang. Beberapa akhir waktu ini di beberapa negara berkembang, daun kelor dapat digunakan sebagai sumber bahan makanan untuk melawan kekurangan gizi pada anak dan merupakan upaya masyarakat dalam meningkatkan sistem kekebalan tubuh (Krisnadi 2015).

Hasil penelitian Hermansyah, Hadju and Bahar (2014), menunjukkan bahwa peningkatan berat badan dapat dipengaruhi oleh pemberian ekstrak daun kelor namun tidak menunjukkan adanya peningkatan asupan ibu hamil yang bekerja pada sektor informal. Daun kelor juga terbukti dapat menaikkan berat badan pada anak tikus 0,1 gram dan menambah panjang badan pada anak tikus sepanjang 0,2 cm (Prihati 2015).

Program Gizi di wilayah Kabupaten Lamongan pada Tahun 2018 difokuskan pada penurunan stunting, salah satu desa prioritas penurunan stunting yakni Desa Datinawong Kecamatan Babat, Kabupaten Lamongan. Mitra dalam program ini adalah kelompok Kader Posyandu di 2 posyandu yaitu Posyandu Dati I dan Dati II. Dimana dalam setiap kegiatan posyandu yang kegiatannya terdapat pada meja 1 sampai 4 dimana kegiatan tersebut adalah mendaftar, menimbang, pengukuran, pencatatan hasil penimbangan dan pengukuran, penyuluhan dan pelayanan gizi bagi Balita. Dalam meja 4, kader tidak pernah memberikan penyuluhan bahkan mengajarkan bagaimana membuat MP-ASI dengan bahan pangan bermacam-macam terutama kelor yang dapat memberikan nutrisi pada anak jika dengan komposisi tepat karena hanya memberikan MP-ASI yang telah dibuat sebelumnya oleh warga tanpa mengetahui kandungan MP- 
ASI tersebut dan kebutuhan gizi anak Balita yang diberikan MP-ASI sehingga sampai saat ini masih terdapat anak stunting.

Mitra pertama dan kedua berharap terdapat program pendampingan pada warga dalam melakukan pengelolaan MP-ASI secara benar, murah dan mudah agar dapat dilakukan dirumah sebagai makanan pendamping anak sampai usia 2 tahun. Namun, mereka tidak cukup informasi untuk mengedukasi para warga. Mitra bersedia memberikan penyuluhan dan cooking class kepada warga setelah dilakukan pelatihan dari tim pengabdian dengan penambahan bahan makanan utama kelor.

\section{METODE}

Setelah melakukan survey lapangan dan menganalisis permasalahan maka metode yang dilakukan adalah Pelatihan Kader, Pendampingan dan Evaluasi terutama pada meja ke empat sekaligus memberikan edukasi (penyegaran) terkait keterampilan kader dalam melaksanakan pengukuran antropometri mengenai cara mengukur tinggi badan dan berat badan Balita secara benar.

\section{HASIL DAN PEMBAHASAN}

Pada tahap pelatihan kader, tim pengabdian masyarakat memberikan informasi selama 1 hari kepada 10 kader mengenai informasi tentang stunting, cara untuk mengukur berat badan dan tinggi badan Balita dengan benar (karena bertepatan di bulan Agustus nanti adalah bulan timbang, diharapkan data yang didapatkan sesuai dengan keadaan Balita), informasi Angka Kecukupan Gizi (AKG), MP-ASI dan dilanjut dengan praktik cooking class dengan bahan dasar kelor. Dalam tahap ini, kader sangat antusias dengan memperhatikan pemberian informasi yang diberikan oleh tim pengabdi dan pertanyaan yang disampaikan oleh kader sangat berbobot menandakan bahwa kader paham dengan apa yang disampaikan, serta saat dilakukan pre dan post test pemberian materi didapatkan hasil pengetahuan yang meningkat pada post test.
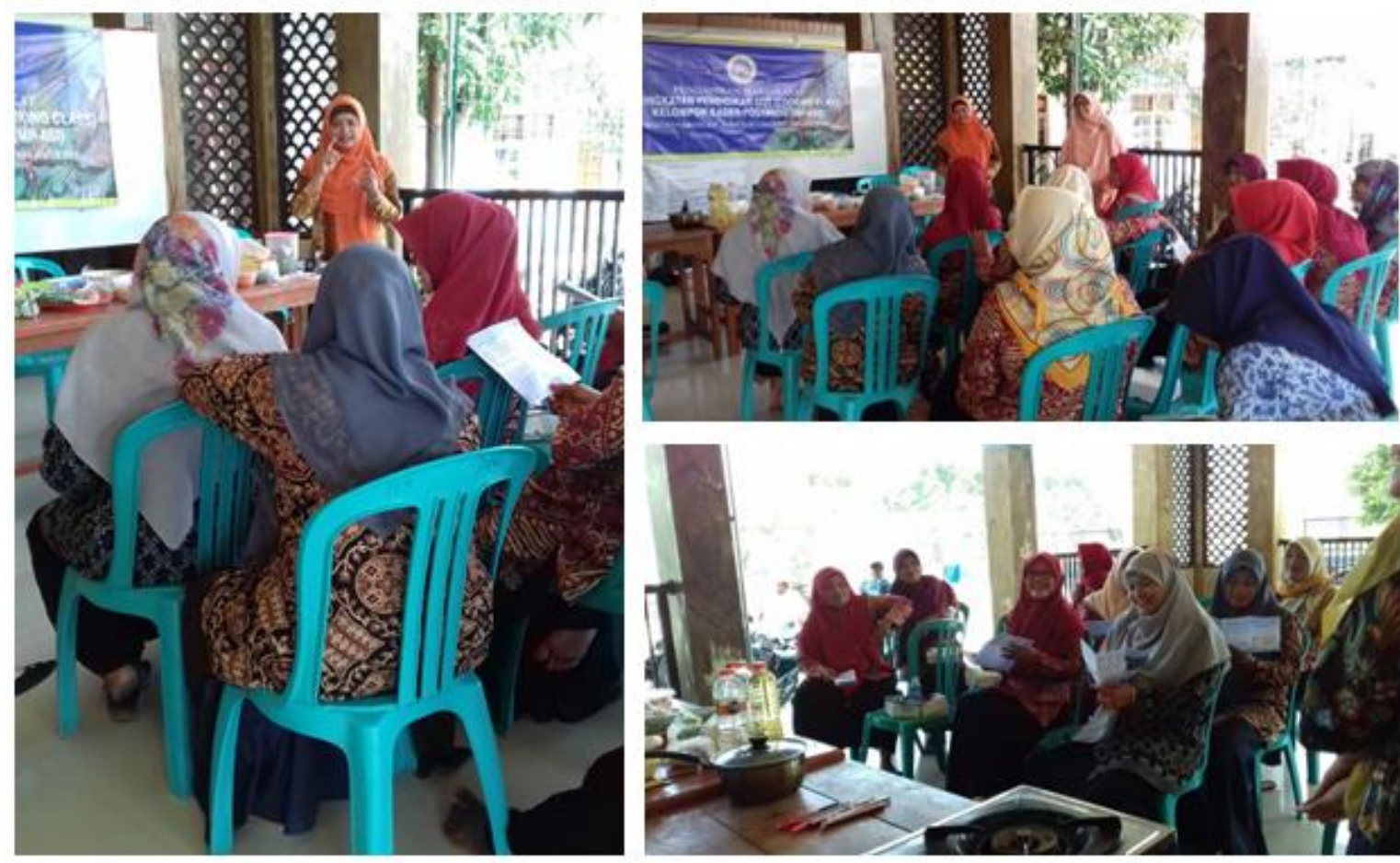

Gambar 1. Pemberian Informasi 


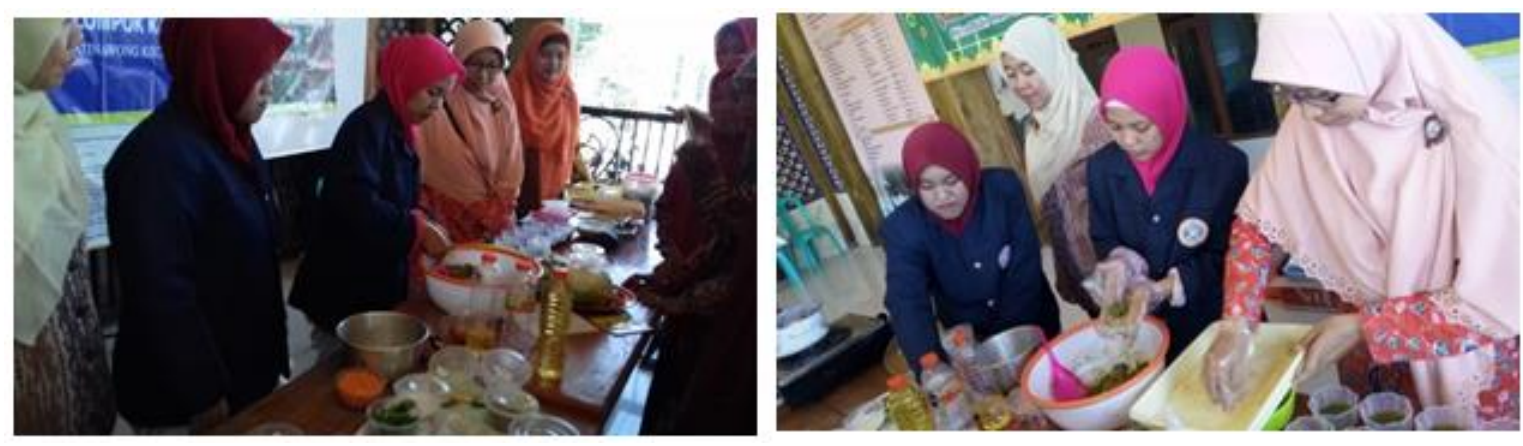

Gambar 2. Pelatihan Cooking Class

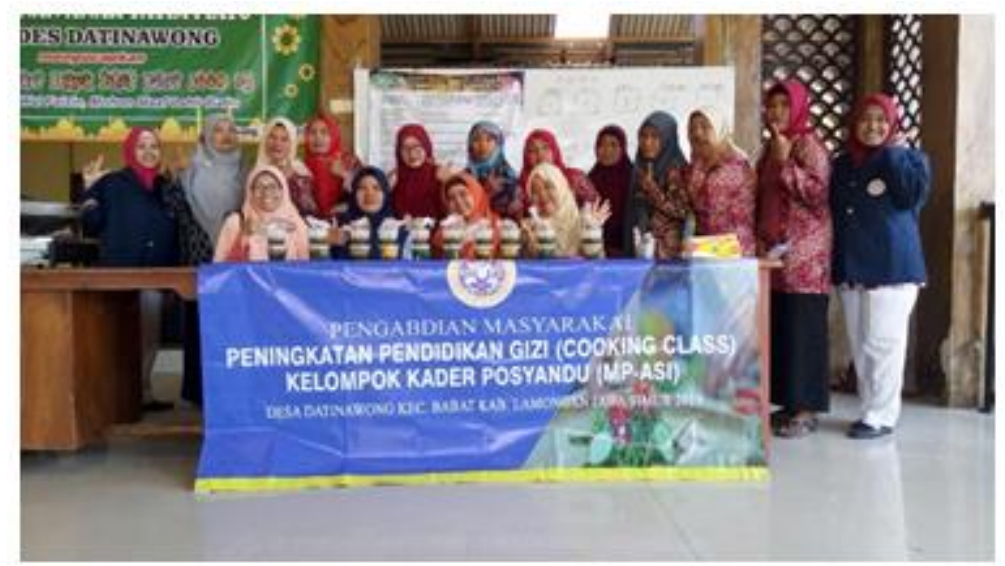

Gambar 3. Hasil Cooking Class (yang dibawa pulang oleh kader)

Setelah dilakukan pelatihan, tahap kedua yaitu pendampingan kepada kader yang dilakukan saat posyandu. Kader memberikan informasi terkait stunting sampai dengan MP-ASI yang baik dan benar berdasarkan usia dalam kecukupan gizi, jumlah dan variasi serta mempraktekkan bagaimana cara mengolah MP-ASI dengan bahan dasar kelor sampai 3 bulan berturut-turut dengan menu berbeda yang mudah, murah dan bergizi. Masyarakat sangat antusias untuk mengikuti kegiatan posyandu di meja 4 ini. Balita yang mengikuti posyandu juga diberikan MP-ASI dari hasil pengolahan bahan dasar kelor oleh Kader saat itu. 


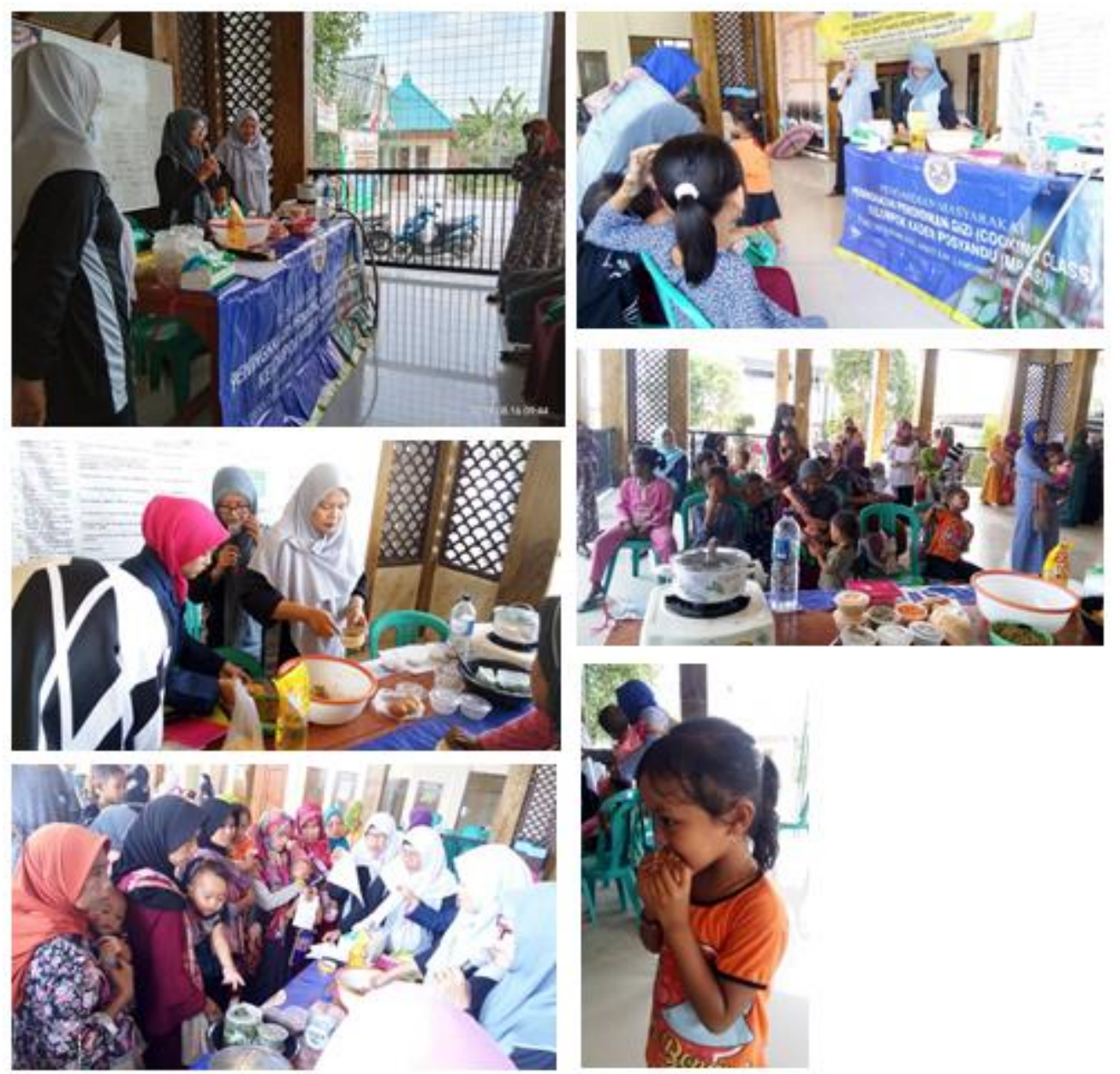

Gambar 4. Kegiatan Pendampingan Kader

(Peningkatan Keberdayaan Mitra dalam meja 4 Posyandu : Penyuluhan dan Cooking Class)

Pada tahap terakhir yaitu evaluasi, dilakukan pertemuan setelah posyandu bulan ketiga berakhir untuk mengevaluasi proses pendampingan yang telah dilakukan oleh kader. Evaluasi yang dilakukan berupa evaluasi proses dan evaluasi hasil. Hasil evaluasi didapatkan bahwa meja 1-4 yang dikerjakan oleh kader posyandu dan tim Puskesmas selama 3 bulan berturut-turut dapat aktif kembali tidak hanya menimbang, mengukur tinggi badan dan mendapatkan MP-ASI lanjut pulang. Masyarakat juga memahami bahwa apa saja yang perlu diberikan kepada anaknya berdasarkan usia, jumlah dan variasinya. Hal ini sejalan dengan penelitian Miskin, Rompas and Ismanto (2016) yang menyatakan bahwa kader sangat berperan dalam kunjungan balita ke posyandu dan berpengaruh terhadap tingkat pengetahuan ibu.

Wahyuningsih and Setiyaningsih (2019) menyatakan bahwa pelaksanaan posyandu ditentukan dari peran kader yang baik dalam melaksanakan kegiatan posyandu. Pelatihan dan pembinaan kader diperlukan untuk dapat meningkatkan keterampilan, informasi serta koordinasi yang baik antara petugas kesehatan dan kader dalam pelaksanaan kegiatan posyandu. Kegiatan ini dapat meningkatkan kehadiran balita ke posyandu (Sayuthi and Ridwan 2016) dengan membuat inovasi terutama untuk memaksimalkan peran kader pada meja 4 Posyandu. Jika posyandu pada meja 1-4 berjalan dengan baik, maka diharapkan angka stunting menurun bahkan tidak terdapat lagi anak dengan stunting, sehingga anak akan tumbuh sebagai penerus bangsa yang hebat dikarenakan gizi yang diterima anak sesuai kebutuhan terutama pada masa golden age ( 2 tahun).

\section{KESIMPULAN}

Pengabdian kepada masyarakat ini dapat disimpulkan bahwa kader dapat memaksimalkan meja ke empat posyandu selama 3 bulan berturut-turut yaitu memberikan penyuluhan bahkan 
mengajarkan kepada ibu balita tentang cara membuat MP-ASI sehingga dapat mendukung program gizi pemerintah dalam upaya menurunkan stunting.

\section{DAFTAR PUSTAKA}

Depkes RI. 2006. "Pedoman Umum Pemberian Makanan Pendamping Air Susu Ibu (MP-ASI) Lokal." Jakarta, 64.

_. 2018. "Buletin Stunting." Kementerian Kesehatan RI 301 (5): 1163-78.

Hermansyah, Veni Hadju, and Burhanuddin Bahar. 2014. "Ekstrak Daun Kelor Terhadap Peningkatan Asupan Dan Berat Badan Ibu Hamil Pekerja Sektor Informal.” Jurnal Ilmu Kesehatan Masyarakat 5 (November): 192-201.

Ibnu, Indra Fajarwati, Muhammad Syafar, and Awaluddin. 2018. "Pemberian Makanan Pendamping ASI (MP-ASI) Pada Ibu Baduta." Prosiding Seminar Nasional PPM 1 (1): 110.

Krisnadi. 2015. Kelor Super Nutrisi. Revisi. Blora: Pusat Informasi Dan Pengembangan Tanaman Kelor Indonesia Lembaga Swadaya Masyarakat Media Peduli Lingkungan (LSMMEPELING).

Miskin, Swengli, Sefti Rompas, and Amatus Yudi Ismanto. 2016. "HUBUNGAN PENGETAHUAN IBU DAN PERAN KADER DENGAN KUNJUNGAN BALITA DI POSYANDU WILAYAH KERJA PUSKESMAS PINELENG." E-Journal Keperawatan 4 (1).

Prihati, Dwi Retna. 2015. "Pengaruh Ekstrak Daun Kelor Terhadap Berat Badan Dan Panjang Badan Anak Tikus Galur Wistar." Jurnal Ilmiah Rekam Medis Dan Informatika Kesehatan 5 (2): 15-22.

Sayuthi, Muhammad, and Arfiza Ridwan. 2016. "Pengetahuan Dan Peran Kader Posyandu Tentang Gizi Balita Di Wilayah Kerja Puskesmas Aceh Besar," 1-8.

Siregar, Mhd Arifin. 2014. "Pemberian ASI Eksklusif Dan Faktor-Faktor Yang Mempengaruhi." Gizi 20 (4): 15-26.

Tim Nasional Percepatan Penanggulangan Kemiskinan. 2018. Strategi Nasional Percepatan Pencegahan Stunting Periode 2018-2024. Jakarta: Sekretariat Wakil Presiden Republik Indonesia.

Wahyuningsih, Wiwid, and Atik Setiyaningsih. 2019. "HUBUNGAN PERAN KADER POSYANDU DENGAN STATUS GIZI CADERE ROLE RELATIONSHIP WITH NUTRITIONAL STATUS OF CHILDREN Pembangunan Kesehatan Masa Yang Sangat Peka Terhadap Masyarakat Sebagai Bagian Dari Upaya Lain Diselenggarakan Melalui Upaya Lin." Jurnal Kebidanan XI (01).

Yanti, Linda, and Kiki Oktaviani. 2012. "Hubungan Waktu Pemberian Makanan Pendamping Air Susu Ibu (MP-ASI) Dengan Status Gizi Pada Bayi Usia 6 - 24 Bulan Di Wilayah Kerja Puskesmas Kalibagor Kabupaten Banyumas." Viva Medika 05: 40-47. 